\title{
M Protein and Protein F Act as Important Determinants of Cell-specific Tropism of Streptococcus pyogenes in Skin Tissue
}

\author{
Nobuhiko Okada, ${ }^{*}$ Alice P. Pentland, ${ }^{\star 5}$ Per Falk, ${ }^{\star \$}$ and Michael G. Caparon* \\ Departments of ${ }^{*}$ Molecular Microbiology, ${ }^{\ddagger}$ Dermatology, and ${ }^{\S}$ Molecular Biology and Pharmacology, \\ Washington University School of Medicine, St. Louis, Missouri 63110-1093
}

\begin{abstract}
The pathogenic gram-positive bacterium Streptococcus pyogenes (group A streptococcus) causes numerous diseases of cutaneous tissue, each of which is initiated after the interaction of the bacterium with the cells of the epidermis. In this study, we show that different surface proteins of $S$. pyogenes play important roles in determining the cell-specific tropism of the bacterium in skin. Using streptococcal strains with defined mutations in the genes which encode surface proteins in combination with primary cultures of human skin and an in situ adherence assay which uses histological sections of human skin, we show that the $M$ protein of $S$. pyogenes mediates the binding of the bacterium to keratinocytes, while a second streptococcal surface protein, protein F, directs the adherence of the organism to Langerhans' cells. Characterization of binding revealed that adherence was inhibited by purified streptococcal proteins and pretreatment of both host cells with the protease typsin. Adherence was only slightly affected by the state of keratinocyte differentiation in vitro, but was considerably modulated in response to environmental conditions known to regulate expression of $M$ protein and protein $F$, suggesting that the interaction between these bacterial cell-surface structures/ adhesins and keratinocytes and Langerhans' cells may play an important role in streptococcal skin disease. (J. Clin. Invest. 1994. 94:965-977.) Key words: streptococcal infection • bacterial adherence $\bullet$ keratinocytes $\bullet$ Langerhans' cells - virulence
\end{abstract}

\section{Introduction}

The cutaneous tissue defines the boundary between the host and the environment and protects against infections of pathogenic agents. In this capacity, the cells of cutaneous tissue encounter a number of pathogenic agents that can induce an inflammatory response. It has been suggested that the epidermal keratinocyte plays an important role in cutaneous inflammation due to its ability to synthesize a number of mediators of inflammation including IL-1 (1). In addition, epidermal keratinocytes contain significant amounts of preformed IL-1 that can be released upon epidermal injury to stimulate the production of chemotactic and

Address correspondence to Michael Caparon, Department of Molecular Microbiology, Washington University School of Medicine, St. Louis, MO 63110-1093.

Received for publication 6 October 1993 and in revised form 23 May 1994.

J. Clin. Invest.

(C) The American Society for Clinical Investigation, Inc.

0021-9738/94/09/0965/13 \$2.00

Volume 94, September 1994, 965-977 cell-activating cytokines such as IL-6 and IL-8, as well as induce local expression of endothelial adhesion molecules (1). However, the molecular mechanisms by which keratinocytes are triggered to initiate inflammatory reactions during infection remain largely unknown.

The gram-positive bacterium Streptococcus pyogenes (group A streptococcus) is one of the most important human pathogens that can infect and colonize cutaneous tissues. $S$. pyogenes causes a number of serious suppurative and inflammatory infections of the skin (impetigo, erysipelas, cellulitis, and necrotizing fasciitis) and of the throat (pharyngitis), as well as poststreptococcal sequelae that produce rheumatic fever and acute glomerulonephritis. Of particular concern is that the incidence of invasive group A streptococcal infections, including the streptococcal toxic shock-like syndrome, has increased dramatically in recent years (2). Skin infections frequently give rise to severe invasive infections and a toxic shock-like syndrome (2). Each streptococcal infection is initiated by the interaction of the bacterium with a host cell, resulting in the generation of a local inflammatory reaction that finally forms severe purulent lesions. This initial interaction is mediated by the binding of structures on the bacterial surface (adhesins) and specific receptors on the surface of host cell.

Several surface components have been identified on the group A streptococci. M protein $(3,4)$ is a prominent molecule on the surface of $S$. pyogenes and is composed of two predominantly alpha-helical protein chains arranged in a coiled-coil conformation. The $\mathbf{M}$ protein is responsible for the protection of the bacterium from phagocytosis by polymorphonuclear leukocytes (5). Lipoteichoic acid (LTA) ${ }^{1}$ is a major constituent of the cell wall of $S$. pyogenes and contains a polyglycerolphosphate backbone linked to a lipid moiety that is normally intercalated into the streptococcal cell membrane (6). Other surface proteins have been described, including a protease with activity against complement components (7), binding proteins with affinity for the Fc region of immunoglobulins (8), and proteins with glyceraldehyde-3-phosphate-dehydrogenase activity that have been reported to bind to a number of different eukaryotic proteins, including plasmin $(9,10)$. The role that any of these structures may play in the interaction with epithelial cells has not been well defined.

It has been suggested that the ability of the $S$. pyogenes to bind the eukaryotic glycoprotein fibronectin plays an important role in the bacterium's initial adherence to epithelial cells of the upper respiratory tract (11). We have investigated the role of the different surface proteins of $S$. pyogenes in fibronectin binding and adherence to the upper respiratory tract epithelium and have identified protein $\mathrm{F}$, a $120-\mathrm{kD}$ surface protein of $S$.

1. Abbreviations used in this paper: DOPA, DL-3,4-dihydroxyphenylalanine; LTA, lipoteichoic acid; THY, Todd-Hewitt medium supplemented with $0.2 \%$ yeast extract. 
Table I. Bacterial Strains Used in This Study

\begin{tabular}{|c|c|c|c|c|}
\hline Strain & Genotype & Phenotype & Comment & Reference or source \\
\hline JRS4 & emm6.1 & $\mathbf{M}^{+}, \mathbf{F}^{+}$ & Wild-type & 53 \\
\hline JRS145 & emm6.200 & $\mathbf{M}^{-}, \mathbf{F}^{+}$ & M protein-deficient derivative of JRS4 & 14 \\
\hline SAM1 & emm6.1 prtF:: $\Omega-1$ & $\mathbf{M}^{+}, \mathbf{F}^{-}$ & Protein F-deficient derivative of JRS4 & 12 \\
\hline SAM2 & emm6.200 prtF:: $\Omega-1$ & $\mathbf{M}^{-}, \mathbf{F}^{-}$ & $\begin{array}{l}\text { M protein - and protein } \mathrm{F} \text {-deficient } \\
\text { derivative of JRS4 }\end{array}$ & 12 \\
\hline $\mathrm{SCH} 7$ & & $\mathbf{M}^{+}, \mathbf{F}^{+}$ & Clinical skin isolate & This study \\
\hline
\end{tabular}

pyogenes, which binds fibronectin at a high affinity (12). In vitro insertional mutagenesis of the gene encoding protein $F$ ( $p r t \mathrm{~F}$ ) followed by allelic replacement of the wild-type gene in both $\mathrm{M}^{+}$and $\mathrm{M}^{-}$isogenic backgrounds, generated mutants of $S$. pyogenes that were unable to bind fibronectin. Significantly, these mutants were completely deficient in the ability to adhere to respiratory epithelial cells independent of the expression of $M$ protein (12). In one study, a gene homologous to prt $F$ was found in all clinical isolates examined (13). Introduction of prt $\mathrm{F}$ into Enterococcus faecalis, a bacterium primarily found in the intestinal tract, conferred upon the bacterium the ability to adhere to respiratory epithelial cells (13) and provided further evidence for the role of protein $F$ in streptococcal-host cell interactions.

While our previous investigations have focused on the respiratory mucosa, the interactions between surface components of $S$. pyogenes and cutaneous tissue are poorly understood, largely due to the lack of a relevant animal model. The human skin consists of the epidermis, which is composed of stratified squamous epithelial cells (keratinocytes), and the dermis, located immediately under the epidermis and composed of connective tissues. In addition to keratinocytes, which comprise the most numerous cell type in the epidermis ( $>90 \%$ ), other distinct resident cell populations are located along the basal layer of the epidermis: among these are the melanin-producing melanocytes and the antigen-presenting Langerhans' cells. In the dermis, the papillary layer of loose connective tissue and a reticular layer of more dense connective tissue can be distinguished. Any of these cells and structures can potentially be involved in serious streptococcal infections.

In this study we have used both primary cultures of human epidermal cells and an in situ adherence assay, which uses histological sections of normal human skin in combination with streptococcal strains with defined mutations in the genes encoding surface proteins, to characterize in molecular detail the interaction of $S$. pyogenes with epithelial cells of the skin. We show that the $\mathrm{M}$ protein of $S$. pyogenes is required for the binding of the bacterium to epidermal keratinocytes, while protein $F$ mediates adherence to Langerhans' cells.

\section{Methods}

Bacterial strains and growth conditions. The bacterial strains used are listed in Table I. A recent clinical isolate of $S$. pyogenes, designated SCH7, was obtained from the St. Louis Children's Hospital. SCH7 was isolated from lesion fluid of a patient with a streptococcal cellulitis, was $\beta$-hemolytic, and was identified as group A streptococci using commercially available diagnostic test kits. $S$. pyogenes was grown in Todd-Hewitt medium (Difco Laboratories Inc., Detroit, MI) supplemented with $0.2 \%$ yeast extract (THY). To produce solid media, Bacto agar (Difco Laboratories Inc.) was added to THY at a final concentration of $1.4 \%$. It has been shown that expression of $M$ protein is stimulated by an elevated level of $\mathrm{CO}_{2}(14)$. Variation in expression of $\mathrm{M}$ protein between liquid and solid cultures was also observed, which is caused by the differential diffusion of $\mathrm{CO}_{2}$ from these two environment (14). Thus, to stimulate expression of $\mathbf{M}$ protein, streptococci were grown in liquid THY at $37^{\circ} \mathrm{C}$ without agitation in culture bottles with airtight sealed tops. Streptococci grown on solid media to repress expression of $\mathrm{M}$ protein were incubated at $37^{\circ} \mathrm{C}$ in ambient air. When appropriate, antibiotics were used at the following concentrations: kanamycin at 500 $\mu \mathrm{g} / \mathrm{ml}$, streptomycin at $1,000 \mu \mathrm{g} / \mathrm{ml}$, and erythromycin at $1 \mu \mathrm{g} / \mathrm{ml}$.

Streptococcal adherence to sections of normal human skin. Samples of normal human skin were obtained from the Department of Dermatology at Washington University following all institutional guidelines concerning human studies. Normal skin specimens were obtained from tissue removed during breast reduction surgery of a healthy individual and were fixed in formalin and subsequently embedded in paraffin. 5$\mu \mathrm{m}$ sections were prepared and used for hematoxylin and eosin staining to identify the architecture of the skin tissue (see Fig. $1 \mathrm{~A}$ ). The adherence assay was performed as described previously (15). Deparaffinized sections were rinsed in water followed by PBS ( $\mathrm{pH} 7.2)$ and then incubated with blocking buffer $(0.2 \%$ bovine serum albumin $/ 0.05 \%$ Tween 20 in PBS). S. pyogenes strains from overnight cultures were harvested by centrifugation, washed in PBS, and resuspended in blocking buffer. A $200-\mu \mathrm{l}$ aliquot of the bacterial suspension $\left(\mathrm{OD}_{600}\right.$ $=1.0$ ) was added to a section of human skin and incubated for $2 \mathrm{~h}$ at room temperature in a humidified chamber. Slides were subsequently washed six times for 5 min each with PBS, stained with acridine orange $(10 \mu \mathrm{g} / \mathrm{ml})$ in $50 \mathrm{mM}$ sodium acetate buffer, $\mathrm{pH} 4.0$, and then examined under a fluorescence microscope. Additional controls for specificity included $E$. faecalis OG1X (16) and recent clinical urinary tract isolate O852, which was obtained from St. Louis Jewish Hospital. These strains were grown and treated in the same manner as $S$. pyogenes strains.

Streptococcal adherence to primary cultures of epidermal cells. Normal human epidermal cell cultures were prepared as described previously (17). The cells were cultured in 24-well plates on type I collagen-coated glass coverslips and maintained in a humidified atmosphere of $5 \% \mathrm{CO}_{2}$ and $95 \%$ air at $37^{\circ} \mathrm{C}$ for 3-4 d before use. When required, the cells were maintained with MCDB153 (GIBCO BRL, Gaithersburg, MD) containing $0.15 \mathrm{mM}$ calcium to produce unstratified cultures. $S$. pyogenes strains from overnight cultures in THY were harvested by centrifugation, washed in PBS, and resuspended in DME to equivalent concentrations $\left(\mathrm{OD}_{600}=0.2\right)$. Aliquots of the bacterial suspensions $(0.5 \mathrm{ml})$ were added to the epidermal cell cultures which were prepared immediately before use by washing three times in DME. The mixture was then incubated for $2 \mathrm{~h}$ at $37^{\circ} \mathrm{C}$ in $5 \% \mathrm{CO}_{2}$. To remove nonadherent streptococci, coverslips were washed in PBS by repeated immersions. The cells were fixed in methanol, stained with Gram stain or acridine 
orange, and examined under a light or fluorescence microscope. For some experiments, the adherence of streptococci was quantified by enumeration of the number of epidermal cells that bound bacteria. At least five randomly chosen microscope fields were examined, and the data were presented as the mean percentage of epidermal cells with at least two adhered streptococci that were present in one microscope field. The enumeration of cells with at least two adhered bacteria provided consistently reproducible results through the elimination of background due to nonspecific binding.

Identification of melanocytes and Langerhans' cells in cultures of epidermal cells. Cultured epidermal cells were infected with $S$. pyogenes strains as described above. After washing to remove unbound bacteria ( see above) the cultured cells were fixed in $4 \%$ paraformaldehyde solution and were washed five times with PBS. For identification of melanocytes, fixed cells were incubated with substrate medium containing DL3,4-dihydroxyphenylalanine (DOPA) (Sigma Immunochemicals, St. Louis, MO) in $0.1 \mathrm{M}$ phosphate buffer, $\mathrm{pH} 6.8$, for $3 \mathrm{~h}$ at $37^{\circ} \mathrm{C}$ (18). They were washed three times with PBS and subjected to an indirect immunofluorescence procedure to stain bacteria as follows: a polyclonal rabbit anti-group A streptococci antiserum (Difco Laboratories Inc.) was diluted at 1:1,000 in PBS and added to the preparations for $1 \mathrm{~h}$ at room temperature. Binding of the streptococcal antiserum was then detected by an FITC-conjugated goat anti-rabbit IgG antiserum (Dako, Glostrup, Denmark). Langerhans' cells were detected by using a mouse monoclonal antibody specific for CD1 (Biosource International, Carmarillo, CA). The antibody was diluted at 1:100 in PBS, was incubated with samples for $1 \mathrm{~h}$, and washed three times with PBS, followed by an FITC-conjugated goat anti-mouse immunoglobulins antiserum (Dako). The location of the bacteria in the samples was then detected by addition of the anti-group $A$ streptocci antiserum and a tetramethylrhodamine isothiocyanate-conjugated goat anti-rabbit IgG antiserum (Sigma Immunochemicals).

Isolation of the streptococcal M6 protein from Escherichia coli. The native M6 protein was partially purified from periplasmic extract from an $E$. coli strain carrying the chimeric plasmid pJRS42.50 (19) which contains the complete M6 protein gene, emm6.1, cloned from wildtype strain JRS4 (20). The M6 protein in the periplasmic fraction was precipitated by $65 \%$ saturated ammonium sulfate. The resulting precipitate was sedimented by centrifugation, resuspended in PBS, and dialyzed against the same buffer. The total protein content of periplasmic extract was $1.5 \mathrm{mg} / \mathrm{ml}$, which was determined by the bicinchoninic acid method (21) with bovine serum albumin as a standard. The protein profiles were monitored by SDS-PAGE, and the presence of the $M$ protein was confirmed by immunoblotting assay using a rabbit anti-M6 protein antiserum (data not shown). The M6 protein contained in periplasmic fraction was $\sim 50 \%$ of total protein as estimated from the Coomassie brilliant blue staining of protein gel. As a control, a periplasmic extract was fractionated using the same procedures from an $E$. coli strain carrying the vector plasmid pUC18 without emm6.1.

Pretreatment of $S$. pyogenes with fibronectin. S. pyogenes strains were cultured overnight at $37^{\circ} \mathrm{C}$ in THY, harvested by centrifugation, and resuspended in PBS containing $1 \%$ Tween 20 (PBS/T) $\left(\mathrm{OD}_{600}\right.$ $=1.0$ ). Aliquots of the bacterial suspensions were incubated with bovine soluble fibronectin $(10 \mu \mathrm{g} / \mathrm{ml})$ for $30 \mathrm{~min}$ at room temperature with agitation. Bacteria were centrifuged and washed three times in $\mathrm{PBS} / \mathrm{T}$ and resuspended in blocking buffer before overlaying skin sections.

Inhibition for streptococcal binding to skin sections. For conditions of inhibition experiments see Table III. Deparaffinized skin sections were incubated with either partially purified M6 protein (up to 750 $\mu \mathrm{g} / \mathrm{ml}$ in PBS) or streptococcal LTA ( $100 \mu \mathrm{g} / \mathrm{ml}$ in PBS) (Sigma Immunochemicals) for $1 \mathrm{~h}$ at room temperature. For periodate oxidation, sections were treated with $10 \mathrm{mM}$ sodium metaperiodate in $50 \mathrm{mM}$ sodium acetate, $\mathrm{pH} 4.5$, for $1 \mathrm{~h}$ at $37^{\circ} \mathrm{C}$ in the dark $(15,22)$. To reduce the aldehyde groups generated by periodate oxidation to alcohol, the sections were then incubated with $50 \mathrm{mM}$ sodium borohydride in PBS for $30 \mathrm{~min}$ at room temperature. For neuraminidase treatment, skin sections were incubated with neuraminidase $(0.2 \mathrm{U} / \mathrm{ml})$ from Vibrio cholerae (Boehringer Mannheim GmbH, Mannheim, Germany) in 50
$\mathrm{mM}$ sodium acetate, $\mathrm{pH} 5.5$, for $2 \mathrm{~h}$ at $37^{\circ} \mathrm{C}$. For trypsin treatment, sections were treated for $1 \mathrm{~h}$ at $37^{\circ} \mathrm{C}$ with trypsin $(5 \mathrm{mg} / \mathrm{ml}$ in PBS) from bovine pancreas (type I; Sigma Immunochemicals), then trypsin inhibitor ( $5 \mathrm{mg} / \mathrm{ml}$ in PBS) from soybean (type I-S; Sigma Immunochemicals) was added to sections immediately to inactivate trypsin protease activity. Control sections were incubated with a mixture of trypsin and trypsin inhibitor ( $5 \mathrm{mg} / \mathrm{ml}$ each). After these pretreatments, skin sections were incubated with blocking buffer for $30 \mathrm{~min}$ at room temperature and then overlaid with the appropriate bacterial suspensions.

\section{Results}

Mutants exhibit cell-specific tropism in cutaneous tissues. We have previously constructed a number of isogenic $S$. pyogenes strains with defined mutations in the genes which encode surface proteins and have demonstrated that protein $\mathrm{F}$, but not $\mathrm{M}$ protein, plays a critical role in adherence to epithelial cells of the upper respiratory tract (12). To characterize the initial events in the development of streptococcal skin infections, we have adopted an in situ assay (15) which uses histologic sections of human skin for the analysis of the adherence properties of various streptococcal mutants (see Table I) that are deficient in expression of specific surface proteins.

In the in situ assay, bacteria were overlaid on sections of formalin-fixed human skin, incubated for $2 \mathrm{~h}$, and then washed extensively to remove unbound organisms (15, see also Methods). The location of the bacteria within the tissue as well as the architecture of the tissue were then visualized by staining with acridine orange. Wild-type $S$. pyogenes strain JRS4 $\left(\mathrm{M}^{+}, \mathrm{F}^{+}\right)$bound in large numbers to cells predominantly located in the epidermis (Fig. $1 B$ ). JRS4 demonstrated only a limited ability to bind to the connective tissues of the dermis (Fig. $1 B$ ), but was found on epithelial cells of the epidermally derived glands, including sweat glands and sebaceous glands (not shown). In contrast, SAM1 $\left(\mathrm{M}^{+}\right.$, $\mathrm{F}^{-}$), an isogenic protein $\mathrm{F}$-deficient derivative of JRS4, bound to epithelial cells of the epidermis in a manner identical to the wild-type strain (Fig. $1 C$ ). SAM1, which still expresses $M$ protein, is unable to adhere to respiratory epithelial cells $(12,13)$. S. pyogenes JRS145 $\left(\mathrm{M}^{-}, \mathrm{F}^{+}\right)$is an isogenic M-deficient derivative of JRS4 (14) which does express protein F (12). While JRS145 bound to cells in the epidermis, striking differences were observed in the distribution of JRS145 when compared with JRS4 and SAM1, in that binding of JRS145 was limited to a population of cells exclusively located along the basal cell layer of the epidermis (Fig. $1 \mathrm{D}$ ). To ensure that this difference was due to the insertional mutation introduced into $\mathrm{emm}$, we examined the binding ability of a recently constructed $S$. pyogenes strain JRS115 $\left(\mathrm{M}^{+}, \mathrm{F}^{+}\right)$where emm6.1 was reintroduced at its wild-type locus in the chromosome of a derivative of JRS4 from which the emm6.1 gene had previously been deleted (23). In adherence to human skin sections, JRS115, like wild-type strain JRS4, bound in large numbers to the epidermis (Fig. $1 E$ ). SAM2 $\left(\mathbf{M}^{-}, \mathrm{F}^{-}\right)$, which expresses neither $M$ protein nor protein $F$, did not bind to any part of the skin tissues (Fig. $1 F$ ). E. faecalis strains OGIX and 0852 also failed to bind to any epidermal cell populations of human cutaneous sections (data not shown). From these data, we conclude that both $M$ protein and protein $F$ are involved in the adherence of $S$. pyogenes to cutaneous tissue but that each protein directs the adherence of the bacterium to different populations of host cells in the epidermis. 

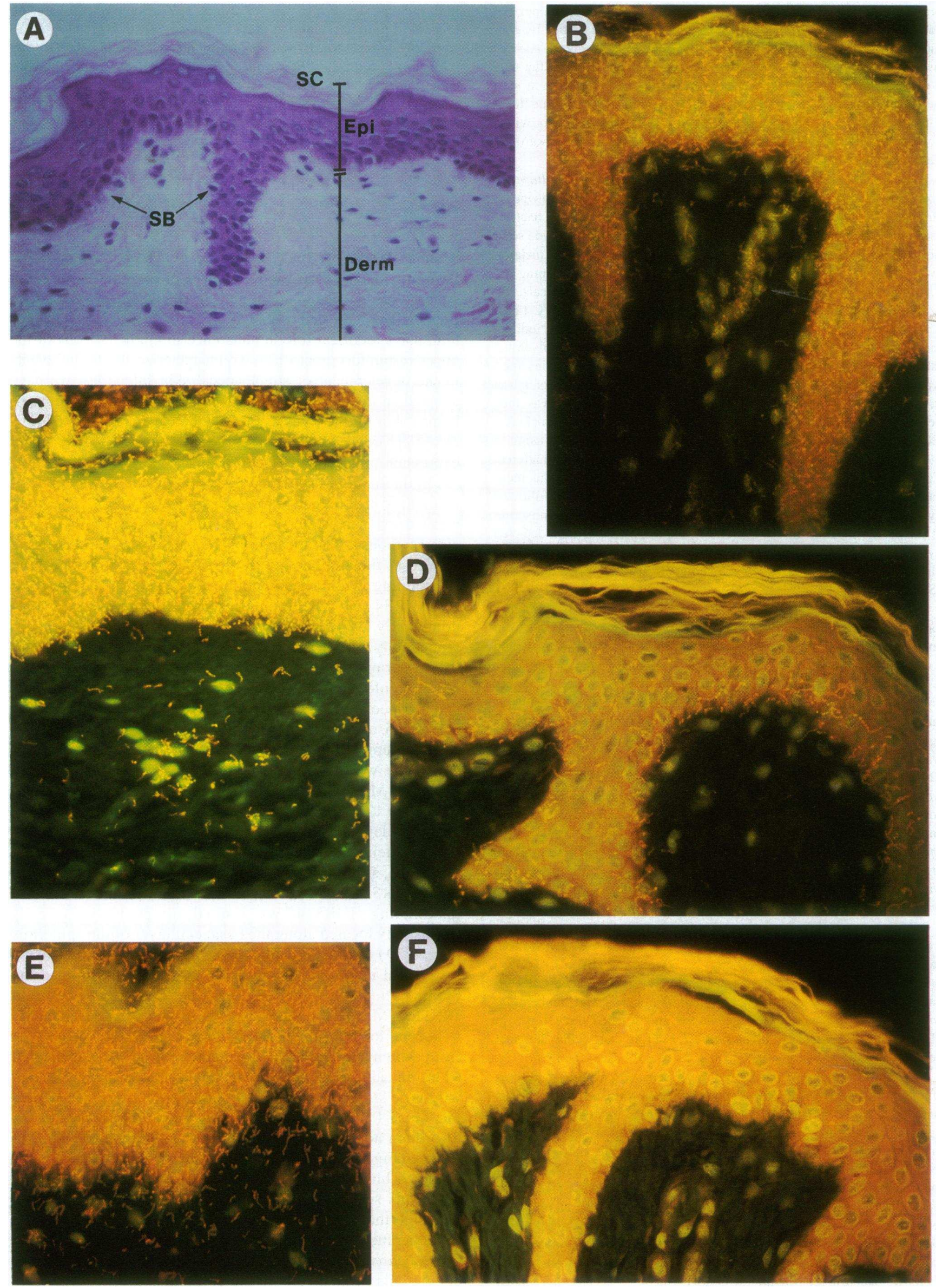
$M$ protein mediates the adherence of $S$. pyogenes to keratinocytes, and protein $F$ directs the binding to Langerhans' cells. Based on the observation that $\mathbf{M}$ protein-mediated and protein $\mathrm{F}$-mediated adherence showed cell-specific localization in the epidermis and from the distribution of adherent bacteria, we hypothesized that strains which express $\mathbf{M}$ protein bound to keratinocytes. Strains which expressed protein F, but were deficient in production of $\mathrm{M}$ protein, adhered to either melanocytes or Langerhans' cells, which are dendritic cells located in the basal cell layer of the epidermis. Because it is difficult to distinguish between these latter two cell types in acridine orange-stained sections of skin, a primary culture of the human epidermal cells was used as a model for streptococcal adherence to cutaneous tissue. Isolated human epidermal cells were incubated with the various streptococcal strains for $2 \mathrm{~h}$, and the adherence of streptococci was assessed by staining the cells with Gram stain or with acridine orange. JRS4 was observed binding in large numbers to the numerous epidermal keratinocytes in the primary culture (Fig. $2 A$ ). The pattern of adherence of SAM1 to the epidermal cells was identical to that of wildtype strain (Fig. $2 B$ ), confirming that $M$ protein mediates the binding of streptococci to epidermal keratinocytes. The differentiation of keratinocytes in cultures can be controlled by calcium (24). When JRS4 was incubated with cultured epidermal cells maintained in low or high calcium media, we found that adherence of streptococci to less differentiated cells (cultured in low calcium media) was only two- to threefold higher than binding of bacteria to the cells more differentiated (cultured in high calcium media) (Table II). While these data suggest that the receptor for $\mathbf{M}$ protein may be expressed at higher levels in undifferentiated keratinocytes, the absence of large difference was consistent with observation that JRS4 was distributed in a similar pattern between more differentiated cells in the suprabasal layers and less differentiated cells in the basal layer in the in situ assay.

As expected, JRS145 only bound to a specific and minor cell population among the cultured epidermal cells (Fig. $2 C$ ). The cells that bound JRS145 were apparently different from keratinocytes based on observation that they frequently appeared morphologically to be dendritic, suggesting they were either melanocytes or Langerhans' cells. Thus, to analyze the protein F-mediated adherence, the cells that bound JRS145 were further characterized using histochemical staining for melanocytes and immunocytochemical staining for Langerhans' cells. After incubation of cultured epidermal cells with JRS145, melanocytes were first distinguished by staining with DOPA for an oxidase reaction specific to melanin-producing cells, which stains them brownish-black, and JRS145 was then detected by an indirect immunofluorescence method (see Methods). JRS145 did not bind to these DOPA oxidase-positive cells (Fig. $3 \mathrm{~A}$ ).

In the normal epidermis, Langerhans' cells are the only cells that express CD1, a surface antigen of thymocytes (25). Therefore, we used this marker for identification of epider- mal Langerhans' cells. Double immunofluorescence staining showed that CD1-positive epidermal cells detected by FITClabeling, but never CD1-negative cells, were identical to the cells that bound JRS145 (Fig. 3, $B$ and $C$ ). These findings demonstrate that protein $\mathrm{F}$ mediates the binding of $S$. pyogenes to epidermal Langerhans' cells. Double mutant SAM2 did not bind at detectable levels to any human cultured epidermal cell of the skin (Fig. $2 D$ ).

Expression of $M$ protein is essential for the adherence of $S$. pyogenes to keratinocytes. The observation that M-deficient strains were no longer capable of binding to epidermal keratinocytes suggests that $\mathrm{M}$ protein is critical for the ability of $S$. pyogenes to adhere to keratinocytes. To confirm this, we examined the ability of wild-type strain JRS4 grown under different conditions to bind to epidermal keratinocytes. It has been shown previously that transcription of the emm6.1 gene that encodes the $\mathrm{M}$ protein (type 6 ) expressed by JRS4 is regulated by $\mathrm{CO}_{2}$ (14). When JRS4 was grown in media with an elevated concentration of $\mathrm{CO}_{2}$ to stimulate expression of $\mathrm{M}$ protein and overlaid on human skin sections, efficient adherence of streptococci to keratinocytes in epidermis was observed. These culture conditions were used for the experiments described above. However, when JRS4 was cultured in media under reduced $\mathrm{CO}_{2}$ tension, conditions which result in a decreased expression of $\mathbf{M}$ protein (14), the ability of JRS4 to bind to keratinocytes was markedly reduced (Table III), and the distribution of adherent cells resembled that of M-deficient mutant JRS145. This environmental modulation of $\mathbf{M}$ protein expression and its effect on epidermal adherence provides additional evidence to suggest that expression of $\mathrm{M}$ protein is essential for the adherence of $S$. pyogenes to keratinocytes.

Partially purified M protein, but not LTA, inhibits the adherence of $S$. pyogenes to keratinocytes. LTA is another streptococcal component exposed on bacterium's surface. While it has been shown that the LTA molecule is not responsible for the adherence of group A streptococci to pharyngeal cells $(12,26)$, it has been suggested that LTA is important for adherence either by directly acting as an adhesin or by mediating a low affinity nonspecific adherence as the result of hydrophobic interactions (27). Therefore, to assess the potential role of the LTA component in the adherence of streptococci to skin tissues, we examined whether streptococcal LTA could block the streptococcal binding to cutaneous tissue. JRS4 was incubated with human skin sections that were preincubated with streptococcal LTA $(100 \mu \mathrm{g} / \mathrm{ml})$ under the conditions described above. No alteration of bacterial binding was observed compared with control experiments that pretreated sections with PBS instead of streptococcal LTA (Table III), suggesting that in this assay the LTA is not involved in the adherence of $S$. pyogenes to cutaneous tissue.

We next examined whether partially purified $\mathbf{M}$ protein could bind to human keratinocytes and inhibit the adherence of intact $S$. pyogenes to epidermal keratinocytes. The M6 protein was partially purified from periplasmic fraction of an $E$. coli

Figure 1. M protein and protein $\mathrm{F}$ exhibit cell-specific tropism of $S$. pyogenes in cutaneous tissue. $A$ shows a section of human skin stained with hematoxylin and eosin showing the epidermis (Epi) which is a layer of stratified squamous epithelium (keratinocytes) and the dermis (Derm) which is composed of connective tissue. The most superficial layer of epidermis, stratum corneum $(S C)$, and the basal layer, stratum basale ( $S B$ ), are indicated. $\times 250 . B-F$ show sections of human skin incubated with $S$. pyogenes: $B, \mathrm{JRS} 4\left(\mathrm{M}^{+}, \mathrm{F}^{+}\right) ; C, \mathrm{SAM} 1\left(\mathrm{M}^{+}, \mathrm{F}^{-}\right) ; D, \mathrm{JRS}^{2} 45\left(\mathrm{M}^{-}\right.$, $\left.\mathrm{F}^{+}\right) ; E$, JRS115 $\left(\mathrm{M}^{+}, \mathrm{F}^{+}\right)$; and $F, \operatorname{SAM} 2\left(\mathrm{M}^{-}, \mathrm{F}^{-}\right)$are shown. The architecture of cutaneous tissue and the distribution of the bacteria within the tissue are visualized by staining with acridine orange. Adherent streptococci are small orange-colored cocci on the skin sections. $\times 400$. 

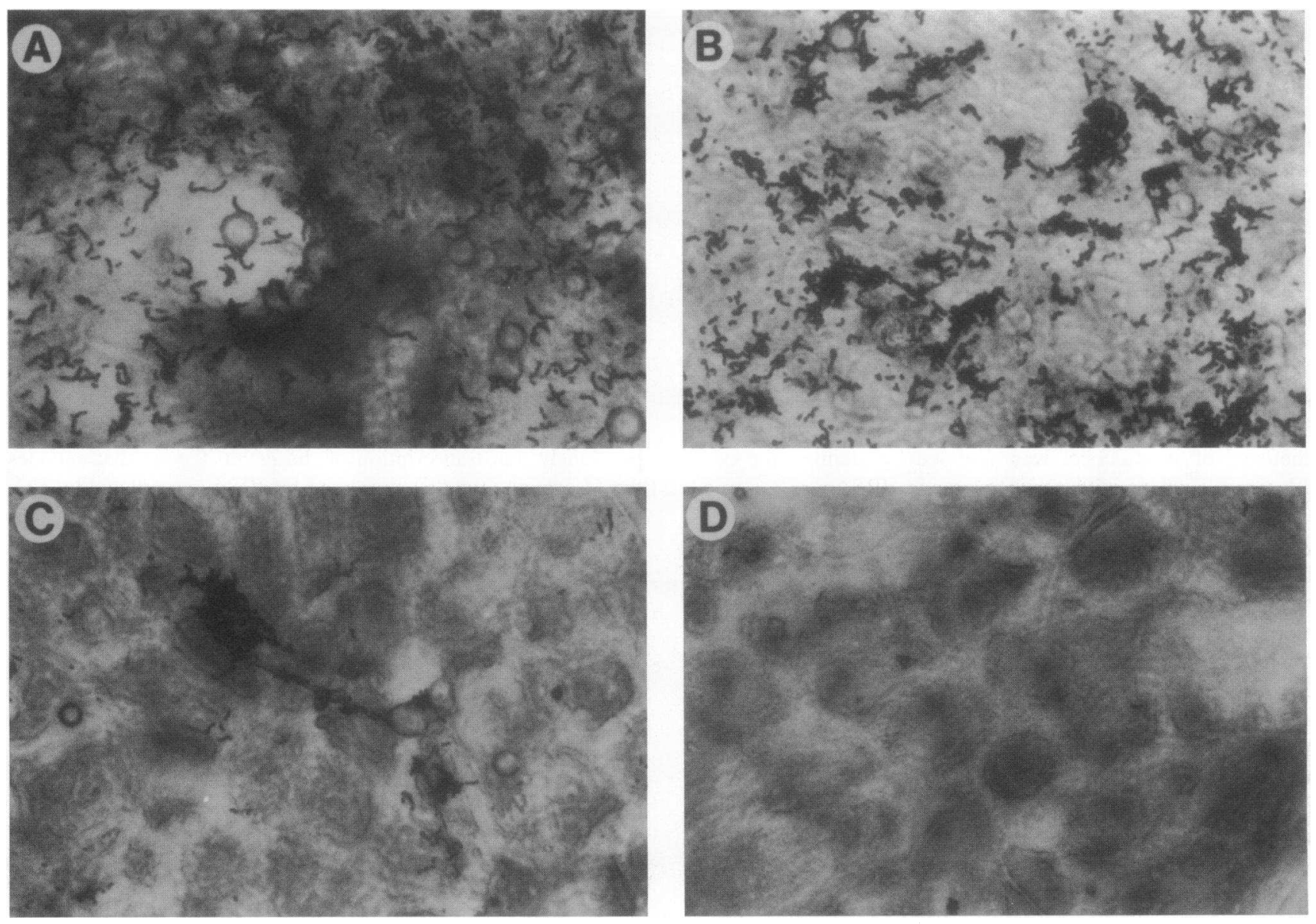

Figure 2. $\mathrm{M}$ protein and protein $\mathrm{F}$ promote the cell-specific adherence in cultured epidermal cells. The adherence of $S$. pyogenes strains $(A) \mathrm{JRS} 4$ $\left(\mathrm{M}^{+}, \mathrm{F}^{+}\right),(B)$ SAM1 $\left(\mathrm{M}^{+}, \mathrm{F}^{-}\right),(C)$ JRS145 $\left(\mathrm{M}^{-}, \mathrm{F}^{+}\right)$, and $(D)$ SAM2 $\left(\mathrm{M}^{-}, \mathrm{F}^{-}\right)$to primary cultures of human epidermal cells is shown. The epidermal cell culture contains three readily identifiable cell populations: keratinocytes (the most numerous cell type of epidermis), melanocytes, and Langerhans' cells. JRS145-binding cells in $C$ possess long dendritic processes. Streptococci, which are small darkly staining cocci on the surface of epidermal cells, are visualized by Gram stain. $\times 330$.

strain that contains the entire emm6.1 gene cloned from JRS4 (19). The binding nature of the M6 protein to human skin sections was tested by using an indirect immunofluorescence method. After incubation of skin sections with M6 proteincontaining periplasmic extracts, the sections were incubated with an $\mathbf{M}$ protein antiserum, and bound antibody was detected

Table II. Adherence of S. pyogenes to Human Epidermal Cells Cultured in Different Calcium Concentrations

\begin{tabular}{lrr}
\hline & \multicolumn{2}{c}{$\begin{array}{c}\text { Percentage of adherence } \\
\text { to epidermal cells* }\end{array}$} \\
\cline { 2 - 3 } & \multicolumn{2}{c}{ Concentration of calcium in medium } \\
\cline { 2 - 3 } Strain & $1.2 \mathrm{mM}$ & $0.15 \mathrm{mM}$ \\
\hline JRS4 & $22 \pm 6$ & $59 \pm 5$ \\
SAM1 & $26 \pm 5$ & $62 \pm 9$ \\
JRS145 & $3 \pm 1$ & $4 \pm 2$ \\
SAM2 & $0 \pm 0$ & $0 \pm 0$ \\
\hline
\end{tabular}

* The number of epidermal cells with at least two bound streptococci was determined by light microscopy. Data represent the mean value and standard error of the mean (see Methods for more details). by indirect immunofluorescence. Binding of partially purified $M$ protein was observed in epidermal cell layers in a pattern similar to the distribution of intact JRS4 bacterial cells (data not shown), providing evidence that $\mathbf{M}$ protein can directly bind to keratinocytes. In addition, the adherence of JRS4 to human skin sections that were pretreated with M6 proteincontaining extracts at a final concentration of $75 \mu \mathrm{g} / \mathrm{ml}$ was remarkably reduced, while complete inhibition of binding was observed when sections were pretreated at higher concentrations (Table III). In contrast, the specific binding of JRS145 to the basal layer of the epidermis was not inhibited by pretreatment of sections with M6 protein-containing fractions even at the highest concentration tested $(750 \mu \mathrm{g} / \mathrm{ml})$, and in control experiments periplasmic proteins from an $E$. coli strain that contained only the cloning vector pUC18, and not emm6.1, had no inhibitory effect.

Fibronectin does not inhibit protein $F$-mediated adherence, but promotes the binding of $S$. pyogenes to the dermis. Protein $\mathrm{F}$ is the fibronectin receptor protein of $S$. pyogenes and binds both soluble and insoluble fibronectins from numerous species, including mouse, bovine, and human (12). Thus, we investigated whether protein $\mathrm{F}$-mediated adherence to epidermal Langerhans' cells could be inhibited by fibronectin. When JRS145 was pretreated with soluble fibronectin and then over- 

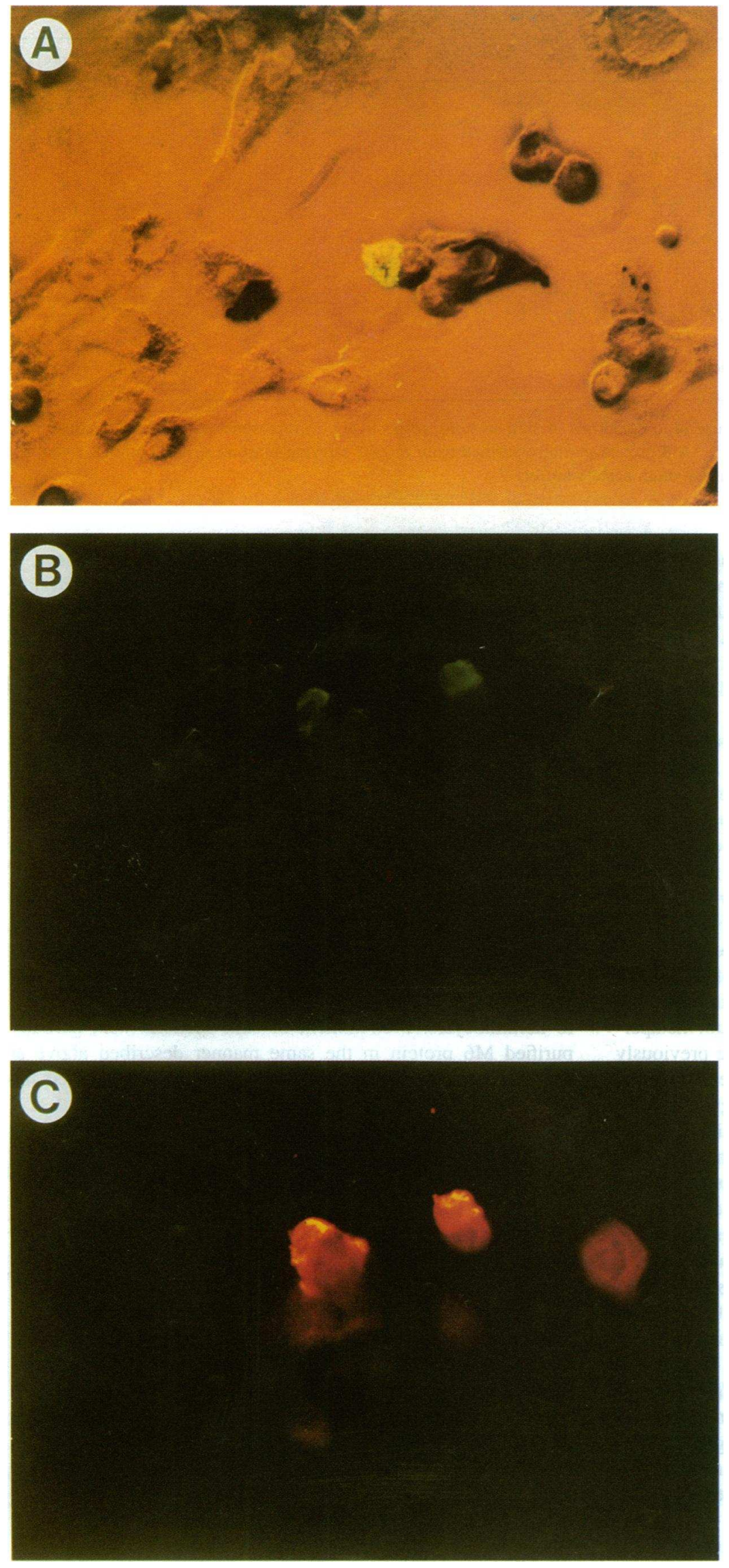

Figure 3. Protein F mediates the adherence of $S$. pyogenes to epidermal Langerhans' cells. Epidermal cells were incubated with JRS145 for $2 \mathrm{~h}$ and then stained to identify the epidermal dendritic cells that bound JRS145. ( $A$ ) Melanocytes detected by DOPA oxidase reaction (see Methods), which appear brownish-black, can be distinguished from the cells that bound JRS145 as detected with antiserum to group A streptococcus and visualized by FITC labeling. ( $B$ and $C$ ) Doublelabeling of cells with anti-CD1 monoclonal antibody and antiserum to group A streptococcus in a single microscopic field reveals that Langerhans' cells labeled with FITC $(B)$ are identical to the cells that bound JRS145 detected by tetramethylrhodamine isothiocyanate labeling $(C), \times 400$. 
Table III. Effects of Various Treatments on Streptococcal Adherence to Epidermis in Human Skin Sections

\begin{tabular}{|c|c|c|c|}
\hline Treatment & Conditions & Inhibition of JRS4* & Inhibition of JRS145* \\
\hline \multicolumn{4}{|l|}{ Bacteria } \\
\hline Grown in low $\mathrm{CO}_{2}$ & & ++ & $\mathrm{NT}^{+}$ \\
\hline Fibronectin & $10 \mu \mathrm{g} / \mathrm{ml}, 30 \mathrm{~min}, \mathrm{RT}^{\S}$ & - & - \\
\hline \multicolumn{4}{|l|}{ Skin section } \\
\hline LTA & $100 \mu \mathrm{g} / \mathrm{ml}, 1 \mathrm{~h}, \mathrm{RT}$ & - & NT \\
\hline \multirow[t]{2}{*}{ M protein" } & $75 \mu \mathrm{g} / \mathrm{ml}, 1 \mathrm{~h}, \mathrm{RT}$ & ++ & NT \\
\hline & $750 \mu \mathrm{g} / \mathrm{ml}, 1 \mathrm{~h}, \mathrm{RT}$ & +++ & - \\
\hline Periodate & $10 \mathrm{mM}$ in $\mathrm{NaAc}^{1}, \mathrm{pH} 4.5,1 \mathrm{~h}, \mathrm{RT}$ & - & - \\
\hline Neuraminidase & $0.2 \mathrm{U} / \mathrm{ml}$ in $\mathrm{NaAc}, \mathrm{pH} 5.5,2 \mathrm{~h}, 37^{\circ} \mathrm{C}$ & - & - \\
\hline Trypsin & $5 \mathrm{mg} / \mathrm{ml}, 1 \mathrm{~h}, 37^{\circ} \mathrm{C}$ & +++ & +++ \\
\hline Trypsin plus trypsin inhibitor & $5 \mathrm{mg} / \mathrm{ml}$ each, $1 \mathrm{~h}, 37^{\circ} \mathrm{C}$ & - & - \\
\hline
\end{tabular}

$*+++$ and ++ indicate no and reduced adherence of bacteria to epidermis of skin sections, respectively. - represents no effect of treatment on bacterial adherence. ${ }^{\ddagger}$ Not tested. ${ }^{8}$ Room temperature. $\quad$ " M6 protein partially purified from $E$. coli carrying plasmid pJRS42.50 that contains the intact emm6.1 gene was used (see Methods). $150 \mathrm{mM}$ sodium acetate buffer.

laid on the sections of human skin, no difference between treated and untreated bacteria was observed in binding to the epidermal Langerhans' cells (Table III). The failure of fibronectin to inhibit adherence suggests that the protein $\mathrm{F}$ molecule possesses distinct domains for binding fibronectin and Langerhans' cells. However, when JRS145 was precoated with fibronectin, a considerably higher level of adherence to the connective tissues of the reticular layer of the dermis was seen when compared with untreated JRS145 (Fig. 4, $A$ and $B$ ), suggesting that soluble fibronectin can serve as an adaptor molecule to mediate the adherence of the bacterium to additional locations in skin. Double mutant SAM2 was not observed bound at any location in the skin, even when preincubated with fibronectin.

Bacterial receptors for $M$ protein as well as protein $F$ are proteins. To characterize the nature of the bacterial receptor on the keratinocytes for M protein and on the Langerhans' cells for protein $\mathrm{F}$, we examined the effects of pretreatment of sections of human skin with sodium metaperiodate, neuraminidase, and trypsin. Human skin sections were treated with sodium metaperiodate under mild oxidation conditions which have previously been shown to inactivate carbohydrate residues essential for the ability of Helicobacter pylori to bind to the pit region of fixed gastric sections, while at the same time not affecting proteins exposed in the sections (15). We observed that there was no reduction in binding of JRS4 or JRS145 to human epidermal cells in periodate-treated sections compared with control sections that were incubated with sodium acetate buffer alone ( Table III). The bacterial binding activity was also insensitive to the treatment of skin sections with the Vibrio cholerae neuraminidase, which hydrolyzes terminal sialic acid from glycoconjugants (Table III). In contrast, a marked decrease in the adherence of both JRS4 and JRS145 was obtained by pretreatment of skin sections with the protease trypsin (Table III). If trypsin inhibitor was included along with trypsin, no effect on bacterial adherence was observed. These data suggest that receptor for $\mathbf{M}$ protein on keratinocytes as well as receptor for protein F on Langerhans' cells have important protein components.

Adherence of a clinical skin isolate of $S$. pyogenes to keratinocytes is dependent on the expression of M protein. We have shown recently that the expression of protein $\mathrm{F}$ in clinical isolates from patients with pharyngitis promotes their adherence ability to respiratory epithelium (13). In a similar manner, if the $M$ protein plays a critical role in adherence of $S$. pyogenes to epidermal keratinocytes, this binding property should also be present in clinical isolates of $S$. pyogenes obtained from skin infections. To test this, $S$. pyogenes $\mathrm{SCH} 7$, a recent isolate from a patient with a streptococcal cellulitis, was cultured in media under high $\mathrm{CO}_{2}$ concentrations to promote expression of $\mathrm{M}$ protein and under reduced $\mathrm{CO}_{2}$ concentrations to repress expression of $\mathbf{M}$ protein, and overlaid on sections of human skin. The adherence of SCH7 grown under conditions that promote $\mathrm{M}$ protein expression was identical to JRS4 (Fig. $5 \mathrm{~A}$ ), while the ability of the streptococci grown under low $\mathrm{CO}_{2}$ to adhere to keratinocytes was substantially reduced, and the pattern of binding resembled that of JRS145, suggesting that clinical cellulitis isolate $\mathrm{SCH} 7$ binds to Langerhans' cells in the epidermis of the human skin (Fig. $5 B$ ). To further demonstrate that the adherence of SCH7 to keratinocytes is mediated by $\mathbf{M}$ protein, we examined if $\mathrm{M}$ protein could inhibit the ability of $\mathrm{SCH}$ 7 to bind to keratinocytes. Pretreatment of skin sections with partially purified M6 protein in the same manner described above at the concentration of $75-750 \mu \mathrm{g} / \mathrm{ml}$ completely inhibited the adherence of $\mathrm{SCH} 7$ to epidermal keratinocytes (Fig. $5 \mathrm{C}$ ). These results suggest that the surface-exposed $C$ repeat region of M protein, which is highly conserved among different $S$. pyogenes strains (3), may be essential for the recognition of receptor on keratinocytes.

\section{Discussion}

The adherence of bacteria to mucosal surfaces is an important prerequisite for bacterial colonization and ensuing disease development (28). In this study we have characterized in molecular detail the interaction between group $A$ streptococci and human cutaneous tissue by adopting both an in situ assay using histologic human skin sections, which was developed to characterize the cell-specific adhesion patterns of $H$. pylori (15), and an in vitro assay which used primary cultures of human epidermal cells. Using these assays in combination with $S$. pyogenes strains that are deficient in specific surface proteins, we have shown that $M$ protein mediates adherence to keratinocytes and protein $F$ directs binding to Langerhans' cells. This conclusion is sup- 

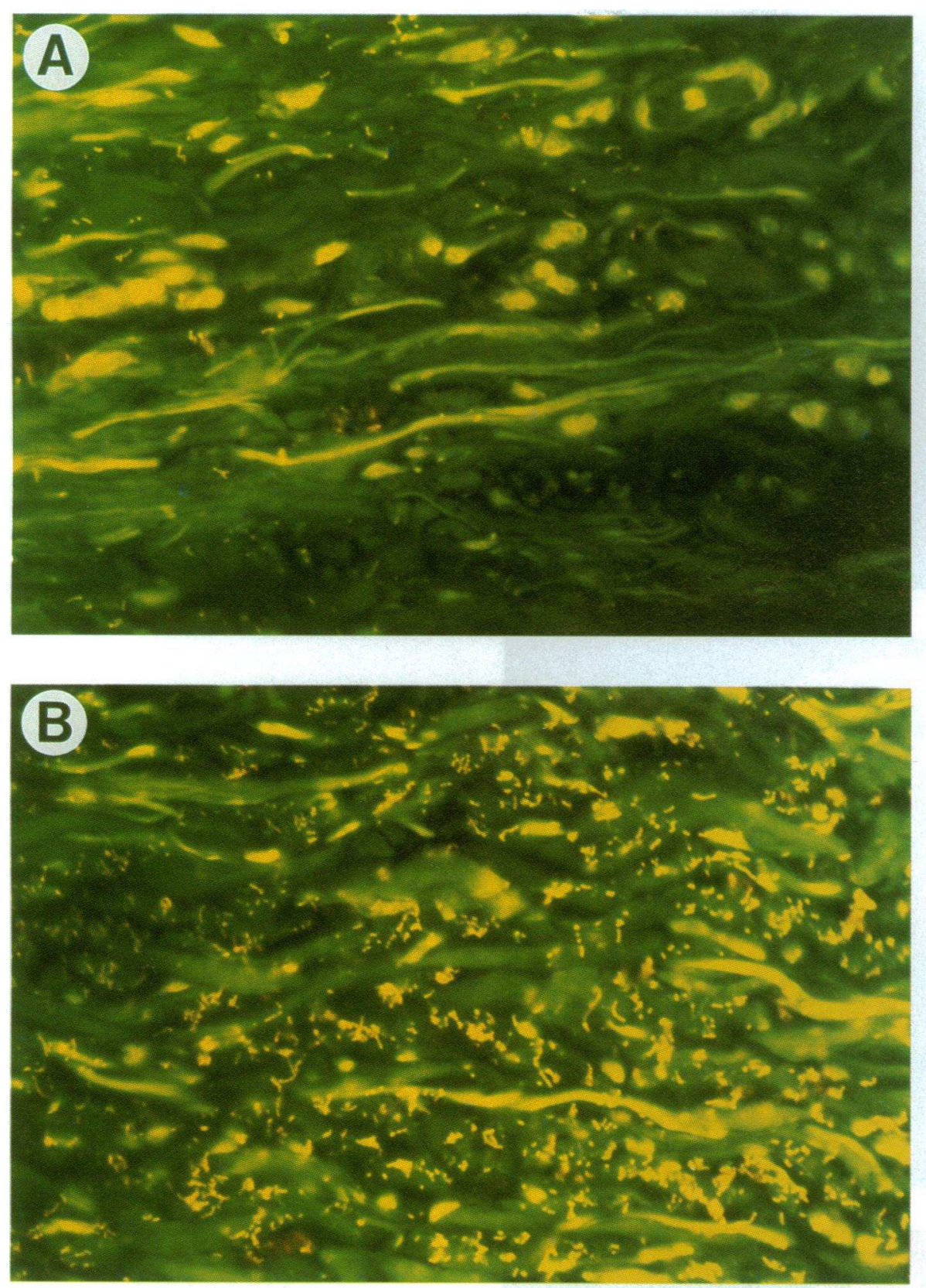

Figure 4. Fibronectin serves as an adaptor molecule to mediate the adherence of $S$. pyogenes to dermis. Effect of fibronectin on adherence of $S$. pyogenes strain JRS 145 to cutaneous tissue was examined on human skin sections (see text for further details). The dermal reticular layer of skin sections incubated with untreated JRS145 $(A)$ and fibronectin-treated JRS145 $(B)$ is shown. Sections were stained with acridine orange.

Orange-colored streptococci that were pretreated with fibronectin show the ability to bind to collagen fibers in the reticular layer of the dermis. $\times 460$. ported by several lines of evidence. Strains which express $M$ protein were able to adhere to epidermal keratinocytes, and an $M$ protein-deficient strain which still expresses protein $\mathrm{F}$ did not adhere to keratinocytes but was capable of binding to Langerhans' cells. Both the wild-type streptococcal strain and a clinical cellulitis isolate did not bind to keratinocytes, when grown under conditions that repress the expression of $\mathbf{M}$ protein. A mutant that expressed neither $M$ protein nor protein $F$ was unable to adhere to any part of the epidermis.

It is likely that these cellular interactions contribute to the pathogenesis of streptococcal disease. Some bacterial surface components, including endotoxins of gram-negative bacteria (29) and cell walls of gram-positive bacteria (30), stimulate cytokine release from eukaryotic cells. Recognition of eukaryotic receptors by pathogenic bacteria also activates inflammatory responses in infected tissues. It has been demonstrated that bacterial attachment to $\mathrm{Gal} \alpha 1-4 \mathrm{Gal}-$ containing receptors for Ppilus of uropathogenic $E$. coli promotes the ability of endotoxin to induce inflammatory responses in the upper urinary tract mucosa (31). In addition, bacterial adherence is involved in the induction of IL- 6 on renal epithelial cells infected with $E$. coli (32). It has also been shown that the purified P-pilus is able to induce a cytokine response by itself in epithelial cell lines of urinary tract origin (33). These observations strongly suggest that bacterial adhesins may mediate mucosal inflammation, not only by bringing bacterial components into contact with mucosal surface, but also by directly stimulating epithelial cells through adhesin-receptor interaction. In the cutaneous tissues, epidermal keratinocytes are thought to play a central role in triggering inflammation both through the release of IL1 and by the production and release of cytokines after stimulation of IL-1 (1). Thus, the molecular interaction between an adhesin of $S$. pyogenes and keratinocytes can provide important 

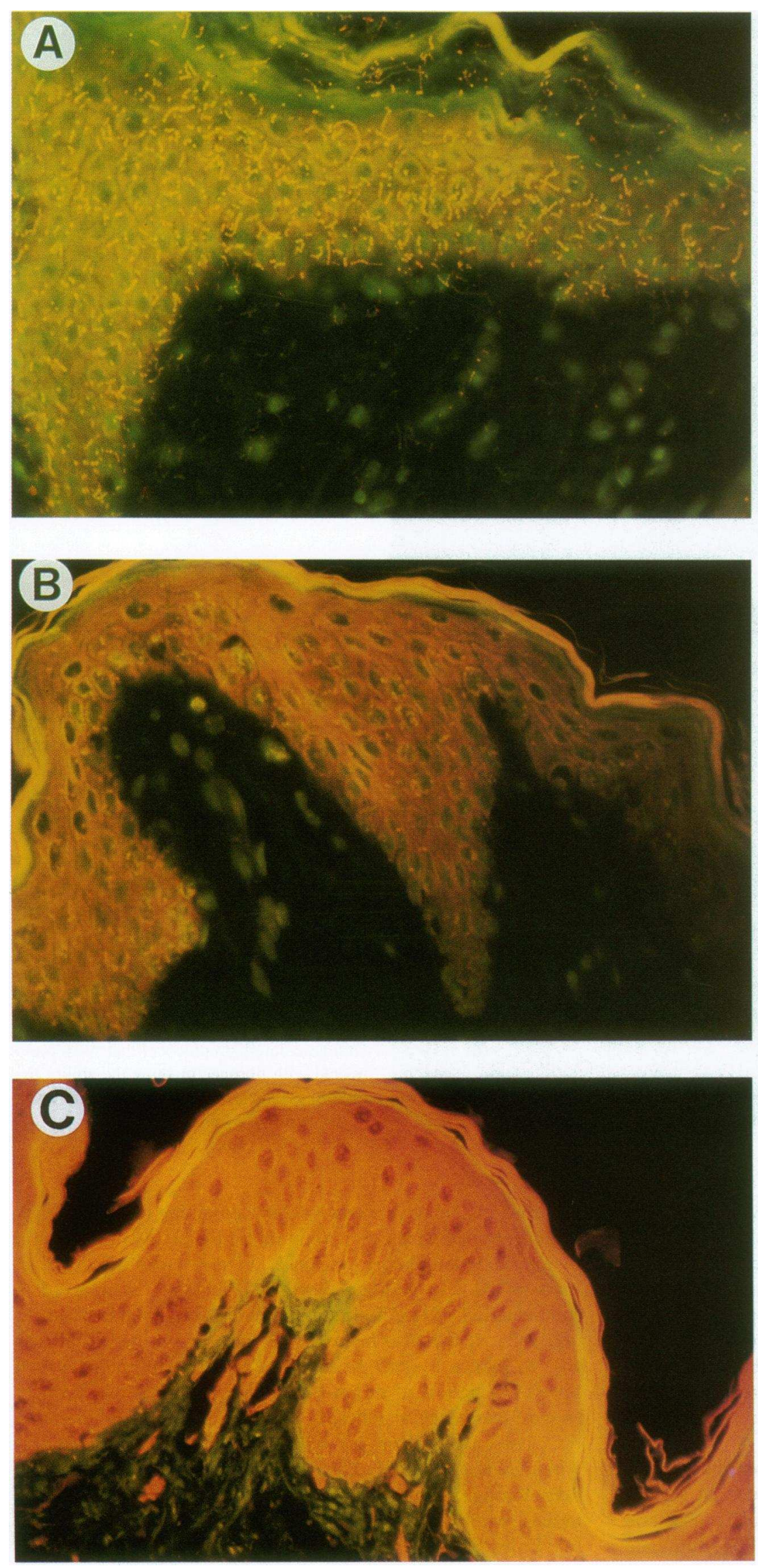

Figure 5. Efficient adherence of $S$. pyogenes $\mathrm{SCH} 7$, a recent clinical isolate from a patient with a streptococcal cellulitis, to epidermis requires expression of $\mathrm{M}$ protein. Skin sections were incubated with $\mathrm{SCH} 7$ strain grown in liquid media $(A)$ and on solid media incubated under an ambient atmosphere $(B)$. Inhibition of the adherence of $\mathrm{SCH} 7$ to epidermal keratinocytes in human skin sections that pretreated with M6 protein-containing extracts $(750 \mu \mathrm{g} / \mathrm{ml})$ is shown (C). Sections were stained with acridine orange. $\times 430$. 
clues to analyze the initiation of an inflammatory host response in streptococcal skin infections.

In addition to the role of a microbial adhesin, host species and cell tropisms are also dependent on the mode of presentation of the host cell receptor. For example, the PapG adhesin at the tip of $E$. coli P-pilus which binds to Gal $\alpha 1-4 \mathrm{Gal}$ moiety of glycolipids is able to adhere to human, but not canine, uroepithelial cell lines, even though both cells express Gal $\alpha 1$ 4Gal-containing glycolipids (34). The recognition of this disaccharide by the PapG adhesin is determined by the conformation of the neighboring sugar residues on the glycolipid, and the composition and structure of these residues differ between human and canine cultured cells (34). In addition, variants of G-adhesins present in different $E$. coli isolates selectively recognize the specific orientation of the saccharide chain in Gal $\alpha 1-4 \mathrm{Gal}$-containing glycolipids (35). Previously, we expressed protein $\mathrm{F}$ in $E$. faecalis, an organism which rarely inhabits the respiratory tract, and found that this organism could now adhere to epithelial cells of the respiratory mucosa, demonstrating that protein $\mathrm{F}$ is an important determinant of tissue tropism of $S$. pyogenes (13). The results described in this paper suggest that $M$ protein may also play a role in determining the tissue specificity of $S$. pyogenes, even though $\mathrm{M}$ protein is not essential for the adherence of the bacteria to pharyngeal mucosa $(12,26)$. While the receptors that are recognized by $\mathbf{M}$ protein and protein $F$ have not been identified, we have demonstrated that both receptors are sensitive to protease trypsin, which suggest that these receptors contain an essential protein component. Identification and characterization of these receptors will be crucial for further analyses of the host cell-adhesin interaction, including the role this interaction plays in the initiation of the inflammatory response that is associated with streptococcal disease.

The inability of fibronectin to inhibit adherence suggests that the binding domain $(s)$ of the protein $F$ molecule that recognizes fibronectin is different from those domains that recognize the Langerhans' cell receptor. A number of surface proteins of the streptococci have been characterized and have been shown to possess functional domains for binding to multiple eukaryotic proteins. $M$ protein, the keratinocyte adhesin, has been shown previously to bind to fibrinogen, a common serum component, the serum $\beta$-globulin factor $\mathbf{H}$, and filamentous actin (3). Streptococcal protein $G$ binds to the Fc region of immunoglobulin $\mathrm{G}(36)$, as well as human serum albumin (37), and some Fc-receptor proteins bind to fibrinogen in addition to immunoglobulin (38). The plasmin receptor/glyceraldehyde-3-phosphate-dehydrogenase proteins display specific binding to many different proteins, including plasmin, fibronectin, lysozyme, and cytoskeletal proteins such as actin and myosin $(9,10)$. Therefore, it is not surprising that protein $\mathrm{F}$ has distinct binding domains responsible for specific binding to fibronectin and to a receptor on the Langerhans' cell. Molecular characterization of these binding domains of protein $\mathrm{F}$ is now in progress.

Langerhans' cells are the principal accessory cells of the immune system located in the epidermis (39). As antigenpresenting cells, Langerhans' cells are involved in the host immune response. For example, Langerhans' cells express high levels of MHC class II molecules (Ia antigen) (39), thymocyte antigen CD1 (25), immunoglobulin $\mathrm{Fc}$ receptor (FcR), and the receptor for complement component C3bi (CR3) (40). In addition, migration of Langerhans' cells from the skin to re- gional lymph nodes provides an efficient means of transporting antigens exposed in the skin to $T$ cells (41). Thus, they may play an important role in the induction and regulation of the immune response in skin lesions. However, the interaction of Langerhans' cells with microorganisms or the role of Langerhans' cells during infection in the skin is not well understood. Streptococcal adherence to these cells was likely not due to a nonspecific antigen-processing function, since it was dependent on a specific surface protein of the streptococcus. Identification of the Langerhans' cell receptor will be required for further analyses of the consequences of this host cell-microbe interaction.

We also found that prior incubation of protein $\mathrm{F}$-bearing streptococci with soluble fibronectin increased the efficiency of adherence of the bacteria/fibronectin complex into the dermis. Fibronectin (42) possesses several structural domains that bind to a number of different molecules including heparin, fibrin (fibrinogen), actin, and collagen. The $\mathrm{NH}_{2}$-terminal $29-\mathrm{kD}$ region of fibronectin contains the receptor for $S$. pyogenes (43) as well as several other types of bacteria, including Staphylococcus aureus (44). Other regions of the fibronectin molecule contain binding domains for additional eukaryotic cell components. For example, the collagen-binding domain is located within a 12$\mathrm{kD}$ fragment that is separate from the $\mathrm{NH}_{2}$-terminal bacteriabinding domain (45). Since the dermis consists primarily of dense collagen fibers, it is likely that the distinct binding domains of fibronectin allow the molecule to serve as an adaptor to connect the bacterium to additional locations in host tissue. This mechanism may be particularly useful in streptococcal wound infection, where the bacterium would expect to encounter soluble fibronectin.

In many bacterial pathogens, expression of virulence factors is affected by environmental conditions $(46,47)$. Typically, recognition of environmental signals such as temperature, osmolarity, iron, $\mathrm{O}_{2}$, or $\mathrm{CO}_{2}$ results in alteration of expression of virulence-associated genes. For $S$. pyogenes, expression of $\mathrm{M}$ protein is highly regulated by the environmental concentration of $\mathrm{CO}_{2}(14)$ and requires mry, a trans-acting positive regulatory gene $(48,49)$. The Mry protein contains domains homologous to other two-component signal transduction proteins (49), and expression of $m r y$ is autoregulated environmentally in response to the level of $\mathrm{CO}_{2}(50)$. We have more recently found that expression of protein $\mathrm{F}$ in clinical isolates of $S$. pyogenes is regulated at transcriptional level in response to $\mathrm{O}_{2}(51)$. JRS4, an extensively laboratory passaged strain, expresses protein $\mathrm{F}$ constitutively, apparently as the result of a mutation in a regulatory gene (51). Even though the $\mathbf{M}$ serotype and expression of $M$ protein in a clinical skin strain were not determined, growth in low $\mathrm{CO}_{2}$ environment nonpermissive for expression of $\mathrm{M}$ protein resulted in loss of ability to bind keratinocytes. This alteration of the binding pattern of a skin isolate under different environmental conditions known to modulate expression of $\mathbf{M}$ protein and protein $F$ supports an important role for $M$ protein in streptococcal adherence to keratinocytes and protein $F$ to Langerhans' cells of the human skin in vivo.

Physiological conditions that promote expression of either protein $\mathrm{F}$ or $\mathrm{M}$ protein tend to repress expression of the other. Environmental conditions at the surface of the skin (high $\mathrm{O}_{2}$ and low $\mathrm{CO}_{2}$ ) may stimulate expression of protein $\mathrm{F}$ but may repress $\mathbf{M}$ protein expression. Since streptococcal skin infections are generally initiated by the implantation of the organism from the surface of the skin into the epidermis by small skin trauma or burns (52), protein F may target the initial adherence 
of the bacteria to Langerhans' cells. Growth in the more $\mathrm{CO}_{2}$ rich, $\mathrm{O}_{2}$-poor environment in the deeper layers of the epidermis may repress expression of protein $F$, stimulate expression of $\mathbf{M}$ protein, and consequently allow the organism to adhere and spread to epidermal keratinocytes. The outcome of these host cell-pathogen interactions may determine the development and severity of the resulting streptococcal disease.

\section{Acknowledgments}

We are grateful for the skilled technical assistance of Debra Yates. We thank Georgy Storch for his generous gifts of SCH7 and Dan Sahm for providing strain 0852 . We also thank V. Fischetti for the gifts of monoclonal antibodies and polyclonal antisera against the M6 protein.

This work was supported by a grant-in-aid from the American Heart Association and by Public Health Service grants AI20723 to M. G. Caparon and AR40574 and DK-38111 to A. P. Pentland. P. Falk is the recipient of a postdoctoral fellowship from the William Keck Foundation.

\section{References}

1. Kupper, T. S. 1990. Immune and inflammatory processes in cutaneous tissues. Mechanisms and speculations. J. Clin. Invest. 86:1783-1789.

2. Stevens, D. L. 1992. Invasive group A streptococcus infections. Clin. Infect. Dis. 14:2-13.

3. Fischetti, V. A. 1989. Streptococcal M protein: molecular design and biological behavior. Clin. Microbiol. Rev. 2:285-314.

4. Scott, J. R. 1990. The M protein of group A streptococcus: evolution and regulation. In Molecular Basis of Bacterial Pathogenesis. B. H. Iglewski and V. L. Clark, editors. Academic Press, Inc., San Diego, CA. 177-204.

5. Lancefield, R. C. 1962. Current knowledge of type-specific $M$ antigens of group A streptococci. J. Immunol. 89:307-313.

6. Wicken, A. J., and K. W. Knox. 1975. Lipoteichoic acids: a new class of bacterial antigen. Science (Wash. DC). 187:1161-1167.

7. Wexler, D. E., E. E. Chenoweth, and P. P. Cleary. 1985. Mechanism of action of the group A streptococcal C5a inactivator. Proc. Natl. Acad. Sci. USA. 82:8144-8148.

8. Heath, D. G., and P. P. Cleary. 1989. Fc-receptor and M protein genes of group A streptococci are products of gene duplication. Proc. Natl. Acad. Sci. USA. 86:4741-4745.

9. Lottenberg, R., C. C. Broder, M. D. P. Boyle, S. J. Kain, B. O. Schroeder, and R. Curtis III. 1992. Cloning, sequence analysis, and expression in Escherichia coli of a streptococcal plasmin receptor. J. Bacteriol. 174:5204-5210.

10. Pancholi, V., and V. A. Fischetti. 1992. A major surface protein on group A streptococci is a glyceraldehyde-3-phosphate-dehydrogenase with multiple binding activity. J. Exp. Med. 176:415-426.

11. Simpson, W. A., H. S. Courtney, and I. Ofek. 1987. Interaction of fibronectin with streptococci: the role of fibronectin as a receptor for Streptococcus pyogenes. Rev. Infect. Dis. 9:S351-S359.

12. Hanski, E., and M. G. Caparon. 1992. Protein F, a fibronectin-binding protein, is an adhesin of the group A streptococcus Streptococcus pyogenes. Proc. Natl. Acad. Sci. USA. 89:6172-6176.

13. Hanski, E., P. A. Horwiz, and M. G. Caparon. 1992. Expression of protein F, the fibronectin-binding protein of Streptococcus pyogenes JRS4, in heterogeneous streptococcal and enterococcal strains promotes their adherence to respiratory epithelial cells. Infect. Immun. 60:5119-5125.

14. Caparon, M. G., R. T. Geist, J. Perez-Casal, and J. R. Scott. 1992. Environmental regulation of virulence in group A streptococci: transcription of the gene encoding M protein is stimulated by carbon dioxide. J. Bacteriol. 174:56935701 .

15. Falk, P., K. A. Roth, T. Borén, T. U. Westblom, J. I. Gordon, and S. Normark. 1993. An in vitro adherence assay reveals that Helicobacter pylor exhibits cell lineage specific tropism in the human gastric epithelium. Proc. Natl. Acad. Sci. USA. 90:2035-2039.

16. Ike, Y., R. A. Craig, B. A. White, Y. Yagi, and D. B. Clewell. 1983 Modification of Streptococcus faecalis sex pheromones after acquisition of plasmid DNA. Proc. Natl. Acad. Sci. USA. 80:5369-5373.

17. Pentland, A. P., M. Mahoney, S. C. Jacobs, and M. J. Holtzman. 1990 Enhanced prostaglandin synthesis after ultraviolet injury is mediated by endogenous histamine stimulation. A mechanism for irradiation erythema. J. Clin. Invest 86:566-574.

18. Vacca, L. L. 1985. Laboratory Manual of Histochemistry. Raven Press, New York. 513-515.
19. Hollingshead, S. K., V. A. Fischetti, and J. R. Scott. 1986. Complete nucleotide sequence of type $6 \mathrm{M}$ protein of the group A streptococcus: repetitive structure and membrane anchor. J. Biol. Chem. 261:1677-1686.

20. Fischetti, V. A., K. F. Jones, B. N. Manjula, and J. R. Scott. 1984 Streptococcal M6 protein expressed in Escherichia coli. Localization, purification, and comparison with streptococcal-derived M protein. J. Exp. Med. 159:10831095.

21. Smith, P. K. R. I. Krohn, G. T. Hermanson, A. K. Mallia, F. J. K. Gartner, M. D. Provenzano, E. K. Fumjimoto, N. M. Goeke, B. J. Olson, and D. C. Klenk 1985. Measurement of protein using bicinchoninic acid. Anal. Biochem. 150:7685.

22. Woodward, M. P., W. W. Young, Jr., and R. A. Bloodgood. 1985. Detection of monoclonal antibodies specific for carbohydrate epitopes using periodate oxidation. J. Immunol. Methods. 78:143-153.

23. Perez-Casal, J., M. G. Caparon, and J. R. Scott. 1992. Introduction of the emm6 gene into an emm-deletion strain of Streptococcus pyogenes restores its ability to resist phagocytosis. Res. Microbiol. 143:549-558.

24. Fuchs, E. 1990. Epidermal differentiation: The bare essentials. J. Cell Biol. 111:2807-2814.

25. Fithian, E., P. Kung, G. Goldstein, M. Rubenfeld, C. Fenoglio, and R. Edelson. 1981. Reactivity of Langerhans cells with hybridoma antibody. Proc. Natl. Acad. Sci. USA. 81:2541-2544.

26. Caparon, M. G., D. S. Stephens, A. Olsén, and J. R. Scott. 1991. Role of $M$ protein in adherence of group A streptococci. Infect. Immun. 59:1811-1817.

27. Hasty, D. L., I. Ofek, H. S. Courtney, and R. J. Dotle. 1992. Multiple adhesins of streptococci. Infect. Immun. 60:2147-2152.

28. Beachey, E. H. 1981. Bacterial adherence: adhesin receptor interactions mediating the attachment of bacteria to mucosal surfaces. J. Infect. Dis. 143:325345.

29. Nawroth, P. P., and D. M. Stern. 1986. Modulation of endothelial cell hemostatic properties by tumor necrosis factors. J. Exp. Med. 163:740-745.

30. Riesenfeld-Orn, I., S. Wolpe, J. F. Garcia-Bustos, M. K. Hoffman, and E. Tuomanen. 1989. Production of interleukin-1 but not tumor necrosis factor by human monocytes stimulated with pneumococcal surface components. Infect. Immun. 57:1890-1893.

31. Linder, H., I. Engberg, I. Mattsby-Baltzer, K. Jann, and C. SvanborgEdén. 1988. Induction of inflammation by Escherichia coli on the mucosal level: requirement for adherence and endotoxin. Infect. Immun. 56:1309-1313.

32. de Man, P., C. Van Kooten, L. Aarden, I. Engberg, and C. SvanborgEdén. 1989. Interleukin- 6 induced at mucosal surfaces by gram-negative bacterial infection. Infect. Immun. 57:3383-3388.

33. Hedges, S., M. Svensson, and C. Svanborg. 1992. Interleukin-6 response of epithelial cell lines to bacterial stimulation in vitro. Infect. Immun. 60:12951301

34. Strömberg, N., B.-I. Marklund, B. Lund, D. Ilver, A. S. Hamers, W. Gaastra, K.-A. Karlsson, and S. Normark. 1990. Host-specificity of uropathogenic Escherichia coli depends on differences in binding specificity to Gal $\alpha 1-4 \mathrm{Gal}$ containing isoreceptors. EMBO (Eur. Mol. Biol. Organ.) J. 9:2001-2010.

35. Strömberg, N., P.-G. Nyholm, I. Pascher, and S. Normark. 1991. Saccharide orientation at the cell surface affects glycolipid receptor function. Proc. Natl. Acad. Sci. USA. 88:9340-9344.

36. Boyle, M. D. P., and K. J. Reis. 1987. Bacterial Fc receptors. Biotechnology. 5:697-703.

37. Björck, L., W. Kastern, G. Lindahl, and K. Widebäck. 1987. Streptococcal protein $\mathrm{G}$ expressed by streptococci or by Escherichia coli, has separate binding sites for human albumin and IgG. Mol. Immunol. 24:1113-1122.

38. O'Toole, P., L. Stenberg, M. Rissler, and G. Lindahl. 1992. Two major classes in the M protein family in group A streptococci. Proc. Natl. Acad. Sci. USA. 89:8661-8665.

39. Stingl, G., S. I. Katz, L. Clement, I. Green, and E. M. Shevach. 1978 Immunologic functions of Ia-bearing epidermal Langerhans cells. J. Immunol. 121:2005-2013

40. Stingl, G., E. C. Wolff-Schreiner, W. J. Pichler, F. Gschnait, W. Knapp, and K. Wolff. 1977. Epidermal Langerhans cells bear Fc and C3 receptors. Nature (Lond.). 268:245-246.

41. Kripke, M. L., C. G. Dunn, A. Jeeven, J. Tang, and C. Bucana. 1990. Evidence that cutaneous antigen-presenting cells migrate to regional lymph nodes during contact sensitization. J. Immunol. 145:2833-2838.

42. Rouslahti, E. 1988. Fibronectin and its receptors. Annu. Rev. Biochem. 57:375-413.

43. Speziale, P., M. Höök, L. M. Switalski, and T. Wadström. 1984. Fibronectin binding to a Streptococcus pyogenes strain. J. Bacteriol. 157:420-427.

44. Mosher, D. F., and R. A. Proctor. 1980. Binding and factor XIIIa-mediated cross-linking of a 27-kilodalton fragment of fibronectin to Staphylococcus aureus. Science (Wash. DC). 209:927-929.

45. Owens, R. J., and F. F. Baralle. 1986. Mapping the collagen-binding site of human fibronectin by expression in Escherichia coli. EMBO (Eur. Mol. Biol. Organ.) J. 5:2825-2830

46. DiRita, V. J., and J. J. Mekalanos. 1989. Genetic regulation of bacteria virulence. Annu. Rev. Genet. 23:455-482.

47. Miller, J. F., J. J. Mekalanos, and S. Falkow. 1989. Coordinate regulation 
and signal transduction in the control of bacterial virulence. Science (Wash. DC). 243:916-921.

48. Caparon, M. G., and J. R. Scott. 1987. Identification of a gene that regulates expression of $\mathbf{M}$ protein, the major virulence determinant of group A streptococci. Proc. Natl. Acad. Sci. USA. 84:8677-8681.

49. Perez-Casal, J., M. G. Caparon, and J. R. Scott. 1991. Mry, a trans-acting positive regulator of the $\mathrm{M}$ protein gene of Streptococcus pyogenes with similarity to the receptor proteins of two-component regulatory systems. J. Bacteriol. 173:2617-2624.

50. Okada, N., R. T. Geist, and M. G. Caparon. 1993. Positive transcriptional control of mry regulates virulence in the group A streptococcus. Mol. Microbiol. 7:893-903.

51. VanHeyningen, T., G. Fogg, D. Yates, E. Hanski, and M. Caparon. 1993. Adherence and fibronectin-binding are environmentally regulated in the group A streptococcus. Mol. Microbiol. 9:1213-1222.

52. Wannamaker, L. W. 1970. Differences between streptococcal infections of the throat and of the skin. N. Engl. J. Med. 282:23-30.

53. Scott, J. R., P. C. Guenthner, L. M. Malone, and V. A. Fischetti. 1986 Conversion of an $\mathrm{M}^{-}$group A streptococcus to $\mathrm{M}^{+}$by transfer of a plasmid containing an M6 gene. J. Exp. Med. 164:1641-1651. 